\title{
Genetics of Threshold Characters and Distribution Cow Calving Traits in Holstein Friesian Cattle at Holeta Bull Dam Station, Ethiopia
}

\section{Gebeyehu Goshu*}

College of Veterinary Medicine and Agriculture, Addis Ababa University, PO Box 34, Bishoftu, Ethiopia

\begin{abstract}
Data collected from at Holeta Bull Dam Station from 118 sires and 902 dams were used to asses distribution of threshold traits as affected by sire variance and calving traits cows. The traits studied were type of birth (normal, abnormal), sex ratio, and female calves reached to age at first calving. Variance analyses were made to estimate effect of sire variances and repeatability of cows on the above threshold traits. The result showed that from the total of 1223 female births, $67.7 \%$ reached to productive age. Sire affected type of birth $(P<0.05)$, sex ratio $(P<0.01)$, and female calves reaching to productive age $(P<0.0001)$. The distribution of calf production traits of cows showed that $30.8 \%$ of cows calved only once, $27.7 \%$ calved abnormal births at least once in their life time and $27.3 \%$ left the herd without producing any female progeny. The probability of a cow repeating abnormal birth, given the previous birth was abnormal, was very high (0.96). It is commendable to test semen for genetic disorder other than milk yield trait to expand dairy production in the country. The number of female calves reaching to productive age can be increased through introduction of sound reproductive management and improving survivability of calves.
\end{abstract}

Keywords: Abnormal births; Friesian; Mortality; Sex ratio; Repeatability; Variance

\section{Introduction}

Threshold traits, such as replacement rate and selective values, are a special class of characters which are qualitative on phenotypic scale but they are, on the contrary, affected by polygenic as well as by environment. Replacement rate is the function of calf production, which is the prenatal calf loss by abortion and still birth, sex ratio, post natal mortality and culling of heifers from birth to reaching the age at first calving [1]. Continuation and profitability of dairy farms are highly dependent on the number of replacement heifers at a given time. Furthermore, information on replacement rate is helpful to estimate the number of inseminations required from each bull to produce a heifer that will reach in the milking herd and the number of lactations a cow should have in the herd to replace herself.

Selective value of an animal is the proportionate contribution of the living female progeny to the next generation. Genetic contribution of a cow to the next generation depends upon productive herd life, longevity, total calves born, total normal calves born, total female calves born and this contribution in the form of living progeny is known as selective value. It is associated with the life time calf production and their survival up to milking age. Replacement rate and selective values are affected by environmental and genetic factors. Colostrum feeding, postcolostral feeding, parity and nutrition of cow, calf hood morbidity and mortality are the major non genetic factors affecting survival of female calves. The productivity of cattle depends largely on their reproductive performance and the survival of calves. Calf morbidity and mortality are problems of major concern in all countries where cattle are raised. Calf diseases are the major constraints for raising replacement stock. They are the results of complex interaction of environment, infectious agents and the calf itself.

Non genetic factors are not the only causes that affect replacement rate and female calves reaching to productive age. Local dairy development is dependent on the importation of semen and sexed semen from temperate countries. As a result, the genotype of the calf is gaining momentum because of its effect on abnormal births and survivability when the same is introduced in unsuitable environment.
The use of insemination and development of methods for dilution and conservation of semen has established the necessary basis for extensive exploitation of sires with a superior genetic constitution. Such elite sires may produce huge numbers of progeny. It is obvious that such extensive use of individual sires may lead to dissemination of undesirable genes within a breed. With the development of methods for semen conservation, inherited disorders changed from mainly having a local effect to having an international effect. This wider perspective means that inherited disorders in dairy cattle have attained international importance.

In Ethiopia, the National Artificial Insemination Center (NAIC) is the only place where semen is produced for use all over the country and is responsible for the coordination of artificial insemination operations in the country. The Holeta Bull Dam Station is the main source of sires for the NAIC. So far, a total of 118 Holstein Friesian young sires were recruited for artificial insemination. This suggests that the cattle breeding activities undergoing throughout the country is largely affected by these centers and, therefore, progressive evaluation of breeding activities on dairy traits help reduce introduction of undesirable characters in to the population. The number of female calves reaching to productive age (age at first calving) from total births is important efficiency parameters for dairy farms. The effect of non genetic factors on birth types, female calf mortality and total calf production for the farm was reported by Gebeyehu and Singh [2]. The objective of the study was to estimate the effect of parental variances on calf production characters in Holstein herd at Holeta.

*Corresponding author: Gebeyehu Goshu, College of Veterinary Medicine and Agriculture, Addis Ababa University, PO Box 34, Bishoftu, Ethiopia, Tel: 0913670532 ; E-mail: ggoshu2000@yahoo.com (or) gebeyehu.goshu@aau.edu.et

Received November 14, 2017; Accepted November 29, 2017; Published November 30, 2017

Citation: Goshu G (2017) Genetics of Threshold Characters and Distribution Cow Calving Traits in Holstein Friesian Cattle at Holeta Bull Dam Station, Ethiopia. J Vet Sci Technol 8: 495. doi: 10.4262/2157-7579.1000495

Copyright: $\odot 2017$ Goshu G. This is an open-access article distributed under the terms of the Creative Commons Attribution License, which permits unrestricted use, distribution, and reproduction in any medium, provided the original author and source are credited. 


\section{Materials and Methods}

\section{Description of the study area}

The Holeta Bull Dam Center is located $33 \mathrm{~km}$ west of Addis Ababa, in West Shoa Zone of Oromia Regional State, Ethiopia and lies on longitude $38^{\circ} 30^{\prime} \mathrm{E}$ and latitude $9^{\circ} 3^{\prime} \mathrm{N}$ at about 2400 meter above sea level. The site is characterized by cool sub-tropical climate with mean maximum and minimum temperatures of $22.3^{\circ} \mathrm{C}$ and $6.16^{\circ} \mathrm{C}$, respectively with the mean relative humidity of $59 \%$. The mean annual rainfall ranged from $818 \mathrm{~mm}$ to $1247 \mathrm{~mm}$ with an average of $1014 \mathrm{~mm} \mathrm{[3].}$

\section{Herd management}

Cows were allowed to graze on native pasture from 8:00 am to 3:00 pm and supplemented with native grass hay on return to the barn in the afternoon. The herd was supplied with cultivated green vetches from December to January and allowed to graze on irrigated pasture from February to May. Most of the cows were served at first observed heat after calving. Heat detections were routinely followed three times in a day, i.e., early in the morning after milking; in the resting period in mid day; and in the afternoon before milking. Calves were separated from their dams after birth and allowed to receive 5, 4, 3, and 2 liters of milk per day from 5 to $65 ; 66$ to $85 ; 86$ to 105 ; and 106 to 120 days of ages, respectively. Regular vaccinations against contagious bovine pleura-pneumonia, lumpy skin disease, anthrax, blackleg, foot and mouth disease and pasteurellosis were given and treatments provided when incidence of cases observed. Culling was practiced as a result of fertility failures, chronic mastitis, tuberculosis, old ages and low daily milk production.

\section{Data source and statistical analyses}

A total of 2983 birth records from 118 sires and 902 cows collected from 1987 to 2011 were used to estimate abnormal births, sex ratio and female calves reached to age at first calving. Abnormal birth includes stillbirth and abortion. A calf born dead between 260 days as full term or calf died within 24 hours after birth is designated as stillbirth while abortion was defined as the loss of the fetus between 42-260 days of pregnancy. Sex ratio is defined as the probability of a cow at a given lactation producing a live female calf. Mortality was considered as the probability of a female calf died before reaching to the age at first calving.

The records of 118 sires were grouped in to ten classes with class width deference of $10 \%$ based on the number of female progenies reached to age at first calving (FAFC) which also included number of successful pregnancies, type of birth (normal $\mathrm{v}$ abnormal) and female births. Likewise, the records of birth traits of 902 cows were tallied from zero (no event on the trait) to 12 (12 calving events) to derive the proportion of different calving traits. A total of 118 sires were used to estimate sire variance while records of 630 cows that had two or above successful pregnancies were used to estimate sire variance and repeatability of a cow trait.

Type of birth, sex ratio, and mortality of female calves are threshold characters or proportion data and was analyzed using the method of Tomar et al. without transformation by conducting the analysis of variance using the following method [4].

Total sum of squares $=\mathrm{pN}-\mathrm{p}^{2} \mathrm{~N}=\mathrm{pqN}$
Sire sum of squares $=\sum p_{i}^{2} n_{i}-p^{2} N=p q N-\sum p_{i} q_{i} n_{i}$

Error sum of squares $=p N-\sum p_{i}^{2} n_{i}=\sum p_{i} q_{i} n_{i}$

Where, $n_{\mathrm{i}}=$ The number of total observations (type of birth, female calves born, female calves reached to age at first calving for the $\mathrm{i}^{\text {th }}$ sire (or cow); $\mathrm{a}_{\mathrm{i}}=$ Number of affected progenies of $\mathrm{i}^{\text {th }}$ sire (or cow).

$\mathrm{N}=\sum \mathrm{n}_{\mathrm{i}}$

$\mathrm{p}_{\mathrm{i}}=\mathrm{a}_{\mathrm{i}} / \mathrm{n}_{\mathrm{i}}$ is the average incidence of the trait among the progenies of $\mathrm{i}^{\text {th }}$ sire (cow)

\section{$\mathrm{q}_{\mathrm{i}}=1-\mathrm{p}_{\mathrm{i}}$}

Sire and cow component of variance $\left(\sigma_{\mathrm{S}}^{2}\right)$ were estimated from the mean squares of between sire or cow $\left(\mathrm{MS}_{\mathrm{S}}\right.$ or $\left.\mathrm{MS}_{\mathrm{C}}\right)$ and within sire/cow component of variance $\left(\sigma^{2}{ }_{\mathrm{w}}\right)$ using the following formula:

$$
\sigma_{S}^{2}=\frac{M S s-M S_{w}}{K} ; \quad \sigma_{C}^{2}=\frac{M S c-M S_{w}}{K}
$$

Where, $\mathrm{K}$ (average number of progenies per sire or cow)=

$$
\begin{aligned}
& \frac{1}{S-1}\left(\frac{\sum n_{i}-\sum n_{i}^{2}}{\sum n_{i}}\right) \\
& \frac{1}{C-1}\left(\frac{\sum n_{i}-\sum n_{i}^{2}}{\sum n_{i}}\right)
\end{aligned}
$$

Where, $\mathrm{S}=$ number of sires; $\mathrm{C}=$ number of cows; $\mathrm{N}=$ total number of observations; $\mathrm{n}_{\mathrm{i}}=$ Number of observations for $\mathrm{i}^{\text {th }}$ sire (or cow).

$$
\text { Repeatability, } \mathrm{r}=\mathrm{t}=\frac{\left(\sigma^{2} c\right)}{\left(\sigma^{2} c+\sigma^{2} w\right)}
$$

Where, $\sigma_{s}^{2}=$ Sire variance component; $\sigma_{c}^{2}=$ cow variance component; $\sigma_{\mathrm{w}}^{2}=\sigma^{2} \mathrm{e}=$ error variance.

Standard errors (SE) for repeatability were computed using the formula.

$$
S E=\sqrt{\frac{p_{1}\left(1-p_{1}\right)}{n_{1}}+\frac{p_{2}\left(1-p_{2}\right)}{n_{2}}}
$$

Where $p_{1}$ and $p_{2}$ where proportions of threshold trait 1 and trait 2 and $n_{1}$ and $n_{2}$ were number of observations for trait 1 and trait 2 , respectively.

\section{Results}

\section{Sire effect}

Table 1 showed that the total number of pregnancies from 118 sires were 2983 of which $12.2 \%$ ended in abnormal births. From the total of 1223 female calves born, 828 (67.7\%) reached to calving age. Less than 50\% of the daughter produced from 32 sires had reached age at first calving. About $14.5 \%$ (17) sires did not have any females reached to the required age although they had 3 female offspring. From the total of sires used for breeding, $46(39.3 \%)$ of them had no abnormal births and the rest gave either abortion or stillbirth with a magnitude ranging from $5.7 \%$ to $50 \%$. Though the number of female calves reached to productive age depends on the number of successful pregnancies and female offspring, there exists clear effect of sire on this trait. Sires had significant effect on abnormal birth $(\mathrm{P}<0.05)$, sex ratio $(\mathrm{P}<0.01)$ and female calves reaching to age at first calving $(\mathrm{P}<0.001)$. The average mortality of female calves reaching productive age was $37.3 \%$ and ranged from $16.7 \%$ to $100 \%$. 
Citation: Goshu G (2017) Genetics of Threshold Characters and Distribution Cow Calving Traits in Holstein Friesian Cattle at Holeta Bull Dam Station, Ethiopia. J Vet Sci Technol 8: 495. doi: 10.4262/2157-7579.1000495

Page 3 of 5

\begin{tabular}{|c|c|c|c|c|c|c|c|c|c|c|}
\hline \multirow{2}{*}{ Class of FAFC $(\%)^{1}$} & \multirow{2}{*}{$\begin{array}{l}\text { No. of } \\
\text { sires }\end{array}$} & \multirow{2}{*}{ Total preg ${ }^{2}$} & \multicolumn{2}{|c|}{ Abnormal birth } & \multicolumn{2}{|c|}{ Normal birth } & \multicolumn{2}{|c|}{ Female births } & \multicolumn{2}{|c|}{ Females reached to AFC } \\
\hline & & & $\mathbf{N}$ & $\%$ & n & $\%$ & $\mathbf{n}$ & $\%$ & $n$ & $\%$ \\
\hline$<10$ & 17 & 60 & 7 & 11.7 & 53 & 88.3 & 3 & 5.7 & 0 & 0.0 \\
\hline $11-20$ & 3 & 124 & 17 & 13.7 & 107 & 86.3 & 56 & 52.3 & 10 & 17.9 \\
\hline $21-30$ & 5 & 59 & 5 & 8.5 & 54 & 91.5 & 25 & 46.3 & 6 & 24.0 \\
\hline $31-40$ & 3 & 233 & 42 & 18.0 & 191 & 82.0 & 91 & 47.6 & 33 & 36.3 \\
\hline $41-50$ & 4 & 234 & 29 & 12.4 & 205 & 87.6 & 102 & 49.8 & 48 & 47.1 \\
\hline $51-60$ & 2 & 125 & 15 & 12.0 & 110 & 88.0 & 44 & 40.0 & 25 & 56.8 \\
\hline $61-70$ & 11 & 989 & 85 & 8.6 & 904 & 91.4 & 425 & 47.0 & 283 & 66.6 \\
\hline $71-80$ & 8 & 401 & 66 & 16.5 & 335 & 83.5 & 164 & 49.0 & 124 & 75.6 \\
\hline $81-90$ & 6 & 196 & 20 & 10.2 & 176 & 89.8 & 90 & 51.1 & 78 & 86.7 \\
\hline$>90$ & 59 & 566 & 78 & 13.8 & 488 & 86.2 & 223 & 45.7 & 221 & 99.1 \\
\hline Overall & 118 & 2983 & 364 & $12.2 \%$ & 2623 & $87.8 \%$ & 1223 & $46.6 \%$ & 828 & $67.7 \%$ \\
\hline \multicolumn{4}{|c|}{ Range of incidence $(\%)$} & $5.7-50$ & \multicolumn{2}{|c|}{$50-94.7$} & \multicolumn{2}{|c|}{$0-100$} & \multicolumn{2}{|c|}{$16.7-100$} \\
\hline \multirow{2}{*}{\multicolumn{2}{|c|}{ Mean squares }} & Sires & \multicolumn{2}{|c|}{$\begin{array}{r}0.0154^{*} \\
(117)\end{array}$} & \multicolumn{2}{|c|}{$\begin{array}{c}0.5569^{* * *} \\
(117)\end{array}$} & \multicolumn{2}{|c|}{$\begin{array}{c}0.3921^{* *} \\
(117)\end{array}$} & \multicolumn{2}{|c|}{$\begin{array}{c}0.5965^{\star * *} \\
(117)\end{array}$} \\
\hline & & Error & \multicolumn{2}{|c|}{$\begin{array}{l}0.1035 \\
(2888)\end{array}$} & \multicolumn{2}{|c|}{$\begin{array}{l}0.0886 \\
(2887)\end{array}$} & \multicolumn{2}{|c|}{$\begin{array}{l}0.2430 \\
(2526)\end{array}$} & \multicolumn{2}{|c|}{$\begin{array}{l}0.1842 \\
(1113)\end{array}$} \\
\hline
\end{tabular}

Table 1: Successful pregnancies, per cent of birth types (normal v abnormal) and female calves reached to age at first calving from 118 sires at Holeta Bull Dam Station.

\begin{tabular}{|c|c|c|c|c|c|c|c|c|c|c|c|c|c|}
\hline \multirow{2}{*}{$\begin{array}{l}\text { Life time calf } \\
\text { Production }\end{array}$} & \multicolumn{13}{|c|}{ Value of traits } \\
\hline & 0 & 1 & 2 & 3 & 4 & 5 & 6 & 7 & 8 & 9 & 10 & 11 & 12 \\
\hline Total births & - & $\begin{array}{l}30.8 \\
(288)\end{array}$ & $\begin{array}{l}18.0 \\
(152)\end{array}$ & $\begin{array}{l}13.0 \\
(117)\end{array}$ & $\begin{array}{c}11.2 \\
(101)\end{array}$ & $\begin{array}{l}8.6 \\
(78)\end{array}$ & $\begin{array}{l}6.7 \\
(60)\end{array}$ & $\begin{array}{l}4.5 \\
(41)\end{array}$ & $\begin{array}{l}4.0 \\
(36)\end{array}$ & $\begin{array}{l}1.6 \\
(14)\end{array}$ & $\begin{array}{l}1.0 \\
(9)\end{array}$ & $\begin{array}{l}0.3 \\
(3)\end{array}$ & $\begin{array}{l}0.3 \\
\text { (3) }\end{array}$ \\
\hline Abnormal births & $\begin{array}{l}65.2 \\
(626)\end{array}$ & $\begin{array}{l}27.7 \\
(212)\end{array}$ & $\begin{array}{l}5.3 \\
(48)\end{array}$ & $\begin{array}{c}1.3 \\
(12)\end{array}$ & $\begin{array}{l}0.2 \\
(2)\end{array}$ & $\begin{array}{l}0.1 \\
(1)\end{array}$ & $\begin{array}{l}0.1 \\
(1)\end{array}$ & $\begin{array}{l}0.0 \\
(0)\end{array}$ & $\begin{array}{l}0.0 \\
(0)\end{array}$ & $\begin{array}{l}0.0 \\
(0)\end{array}$ & $\begin{array}{l}0.0 \\
(0)\end{array}$ & $\begin{array}{l}0.0 \\
(0)\end{array}$ & $\begin{array}{l}0.0 \\
(0)\end{array}$ \\
\hline Normal births & $\begin{array}{l}7.1 \\
(47)\end{array}$ & $\begin{array}{l}31.6 \\
(285)\end{array}$ & $\begin{array}{l}18.5 \\
(167)\end{array}$ & $\begin{array}{l}11.8 \\
(106)\end{array}$ & $\begin{array}{c}9.9 \\
(89)\end{array}$ & $\begin{array}{c}9.4 \\
(85)\end{array}$ & $\begin{array}{l}5.4 \\
(49)\end{array}$ & $\begin{array}{l}3.2 \\
(29)\end{array}$ & $\begin{array}{l}2.8 \\
(25)\end{array}$ & $\begin{array}{l}1.2 \\
(11)\end{array}$ & $\begin{array}{l}0.9 \\
(8)\end{array}$ & $\begin{array}{l}0.1 \\
(1)\end{array}$ & $\begin{array}{l}0.0 \\
(0)\end{array}$ \\
\hline Female calf birth & $\begin{array}{l}27.3 \\
(246)\end{array}$ & $\begin{array}{l}33.1 \\
(299)\end{array}$ & $\begin{array}{l}20.1 \\
(181)\end{array}$ & $\begin{array}{l}11.0 \\
(99)\end{array}$ & $\begin{array}{l}5.8 \\
(52)\end{array}$ & $\begin{array}{c}1.9 \\
(17)\end{array}$ & $\begin{array}{l}0.5 \\
(4)\end{array}$ & $\begin{array}{l}0.4 \\
(3)\end{array}$ & $\begin{array}{l}0.0 \\
(1)\end{array}$ & $\begin{array}{l}0.0 \\
(0)\end{array}$ & $\begin{array}{l}0.0 \\
(0)\end{array}$ & $\begin{array}{l}0.0 \\
(0)\end{array}$ & $\begin{array}{l}0.0 \\
(0)\end{array}$ \\
\hline Female calf loss & $\begin{array}{l}69.2 \\
(451)\end{array}$ & $\begin{array}{l}25.1 \\
(145)\end{array}$ & $\begin{array}{l}4.9 \\
(44)\end{array}$ & $\begin{array}{l}0.9 \\
(8)\end{array}$ & $\begin{array}{l}0.2 \\
(0)\end{array}$ & $\begin{array}{l}0.0 \\
(0)\end{array}$ & $\begin{array}{l}0.0 \\
(0)\end{array}$ & $\begin{array}{l}0.0 \\
(0)\end{array}$ & $\begin{array}{l}0.0 \\
(0)\end{array}$ & $\begin{array}{l}0.0 \\
(0)\end{array}$ & $\begin{array}{l}0.0 \\
(0)\end{array}$ & $\begin{array}{l}0.0 \\
(0)\end{array}$ & $\begin{array}{l}0.0 \\
(0)\end{array}$ \\
\hline $\begin{array}{l}\text { Female calf reached to } \\
\text { milking herd }\end{array}$ & $\begin{array}{l}45.7 \\
(412)\end{array}$ & $\begin{array}{l}28.4 \\
(256)\end{array}$ & $\begin{array}{l}16.1 \\
(151)\end{array}$ & $\begin{array}{l}6.5 \\
(59)\end{array}$ & $\begin{array}{l}2.4 \\
(22)\end{array}$ & $\begin{array}{l}0.6 \\
(5)\end{array}$ & $\begin{array}{l}0.2 \\
(2)\end{array}$ & $\begin{array}{l}0.1 \\
(1)\end{array}$ & $\begin{array}{l}0.0 \\
(0)\end{array}$ & $\begin{array}{l}0.0 \\
(0)\end{array}$ & $\begin{array}{l}0.0 \\
(0)\end{array}$ & $\begin{array}{l}0.0 \\
(0)\end{array}$ & $\begin{array}{l}0.0 \\
(0)\end{array}$ \\
\hline
\end{tabular}

Figures in parenthesis are number of observation under each category.

Table 2: Percentage distribution of cows for life time calf production traits $(n=902)$ at Holeta Bull Dam Station.

\begin{tabular}{|c|c|}
\hline Trait & Repeatability \pm SE \\
\hline Abnormal births & $0.964 \pm 0.012$ \\
\hline Normal birth & $0.176 \pm 0.008$ \\
\hline Sex ratio & $0.038 \pm 0.017$ \\
\hline Mortality & $0.060 \pm 0.028$ \\
\hline Replacement rate from total pregnancy & $0.780 \pm 0.019$ \\
\hline Replacement rate from female calves born & $-0.240 \pm 0.022$ \\
\hline
\end{tabular}

Table 3: Repeatability of threshold traits in Holstein Friesian herd at Holeta Bull Dam Station.

\section{Distribution of cows according to daughters reached to productive age}

The percent distribution of cows for life time calving (calf production) revealed that $30.8 \%$ of total cows calved only once and the proportion was only $0.3 \%$ for the cows that calved 11 and 12 times (Table 2). About $65.2 \%$ of cows calved normal throughout their life time calf production, while $27.7 \%$ cows gave abnormal births in their first calving. Moreover, $7.1 \%$ of total cows left the herd without any normal calving while $31.6 \%$ cows calved normal once, $18.5 \%$ calved normal twice. About $27.3 \%$ and $45.7 \%$ of the cows left the herd without producing any female calf or replacing themselves. The percentage of different calf production attributes decreases as the frequency of calving increases.

\section{Repeatability of threshold traits}

Table 3 depicted the repeatability estimates for some threshold characters. The repeatability of a cow giving abnormal birth in the next generation is very high (0.964), while the estimate of mortality and sex ratio observed were very low and ranged from $0.060 \pm 0.028$ to 0.038 \pm 0.017 , respectively. Negative repeatability means the value is close to zero.

\section{Discussion}

\section{Sire effect}

The effect of sire on different types of birth and female calves reaching the age at first calving and analysis of variances showed in Table 1 . The number of female calves reached to production age is a function of successful pregnancies, normal calves born, and mortality/ culling of female calves. As a result, from 828 female calves only $67.7 \%$ was joined the milking herd as a replacement cows. This is very low rate for dairy farms. The variance analysis shows that sire variance components significantly affected all traits. Previous report on the same data set showed that $\mathrm{h}^{2}$ values for abnormal births, mortality and culling were $0.16 \pm 0.009,0.18 \pm 0.029$ and $0.71 \pm 0.029$, respectively [2]. This indicates that there is sufficient additive genetic variance 
affecting these threshold traits. Since sires are recruited based on milk yield performance of the parents, the negative effect on non production traits cannot be ruled out. Current international breeding goals include functional traits such as fertility, udder health type trait and functional survival. When a carrier animal is extensively used for breeding purposes, as in the case of sires for artificial insemination, several thousand calves may be sired by the carrier bull before the abnormality expresses itself. Therefore, it is prudent to test sires from which semen or sexed semen will be marketed as well as donor dams in embryo transfer programs for known genetic defects. This demands the necessity of including survival traits in the selection criteria when recruiting sires for production traits. Genotyping of animals by genomic analysis has efficiently reduced the prevalence of bovine leukocyte adhesion deficiency, complex vertebral malformation and spinal dysmyelination [5]. Moreover, Donagh et al. reported that selection for increased milk production alone without any cognizance of other trait is expected to increase the incidence of mastitis, lameness, cystic ovaries, ketosis and metritis [6].

Part of the phenotypic variance expressed on these threshold traits is contributed by environmental (non genetic) variance. The sex of a calf is determined by the ' $\mathrm{X}$ ' chromosome contributed by the sire during fertilization. Although the female to male ratio expected to be $1: 1$, the same result may not be achieved during artificial mating. Studies by Berry and Cromie, Zobel et al. and Gebeyehu and Singh showed that the proportion of male calves born from artificial insemination is relatively higher than female births. The effect of freezing temperature on the various attributes of spermatozoa and different sires might have responded differently to liquid nitrogen preservation $[2,7,8]$.

The analysis of variance revealed that sire differences in prenatal mortality due abnormal birth in Holstein Friesian cattle were statistically significant $(\mathrm{P} \leq 0.01)$. Quite a high and varying proportions of sires used in breeding have been observed affecting the abnormal birth of calf by Kumar et al. in Sahiwal (70\%) and Holstein Friesian (82\%) and Atrey et al. in Frieswal bull (95\%) $[9,10]$.

\section{Distribution of cows according to daughters reached to productive age}

A third of cows left the herd only calving once indicated that the highest culling of cows could be on the basis of first lactation milk yield, prevalence of abortion and stillbirths. The present estimate was but lower than that Atrey et al. in Frieswal cattle [10]. The difference in observations could be variations in culling rate, availability of replacement heifers and management practices at different dairy cattle farms.

About $27.7 \%$ of the cows calved abnormally during their first calving and proportion decreases as parity increases. This might be associated to the calving difficulty young cows as a result of undeveloped reproductive systems and to some genetic inheritance. Fries and Ruvinsky reviewed the genetic and biology of reproduction of cattle and showed that incidence of dystocia is three to four times as frequent in females calving for the first time compared to females in the second parity and the same was attributed to lighter body weight of first calvers because of the lesser skeletal development relative to mature female cow, and sex of the calf [11].

The percent distribution of cows according to the number of calving in their life time indicated that $7.1 \%$ of total cows left the herd without any normal calving. The observed value was higher than that reported
Singh [12]. The difference in observation of various workers could be attributed to the genetic (breed) and environmental (feeding) reasons.

A good proportion of cows left the herd without producing female calves could be related to artificial insemination practices maintained in the farm in addition to abortion, stillbirth and calf death. Plethora of reports indicated that high male calf birth rate was observed when cows were inseminated artificially [2,7], place of deposition of semen [8] and time of insemination after standing heat [13]. At Holeta station, the artificial insemination service was based on frozen semen collected from imported Holstein Friesian bulls and young male calves selected from those bull calves born at the farm. This might affect the capacitating ability of X-chromosome bearing sperm cells. Moreover, recent studies supported sex allocation hypothesis of Triver-Wilson. The amount of weight body lost between calving and conception and the rate of loss affected the sex of resultant offspring. Less weight loss or greater weight gain between calving and conception was associated with greater likelihood of a male calf. Although concurrent records were not available the present finding suggests the necessity of monitoring the body condition of dairy cows at different physiological stage [14] However, a comparison of artificial versus natural mating on 4657 caving events of indigenous and their crosses with Friesian and Jersey at Holeta Research Center showed that use of sire resulted in skewed male births [15]. Since reports on sex ratio are usually from breeding centers, this calls for investigation of artificial insemination under farmers' condition. The present sex ratio was closer to the findings of Silva et al. who reported calf sex ratio of $53.3 \%$ male and $46.7 \%$ female for singleton in Friesian cows [16]. The varying percentage of cows which were failed to produce any female calf have been observed for Friesian crosses Singh [12] for Karan Fries and Atrey et al. for Frieswal cows [10].

Moreover, mortality of calves in the first few months of birth could contribute to the low number of replacements. The average mortality rate from birth to age at first calving among the Holstein Friesian female calves born was found to be $23 \%$ at Holeta farm. This rate of mortality was high and could be related to health problems and inadequate feeding management of female calves. Wudu reported that calf diarrhea was the leading cause of calf morbidity with incidence rate of $42.9 \%$ followed by pneumonia (4.9\%) [17]. Similarly, Berhanu et al. reported that from the total of 97 calf deaths recorded in $1^{\text {st }}$ parity cows, $7.2 \%, 3.1 \%$ and $5.2 \%$ were associated with pneumonia, calf scour and sudden death, respectively and $71.2 \%$ calf deaths were not known [18]. Absence of mechanism for controlling sexually transmitted diseases could contribute to the incidence rate of mortality. Desalegne reported that bulls were recruited in the absence of tests for bovine brucellosis, bovine tuberculsosis, bovine viral diarrhea, infectious bovine rhinotracheitis, campylobacter and bovine trichomoniasis [19]. Though the routine recording system was not efficient enough to identify the real causes abortion and mortality, it can be hypothesized that inherited genetic disorders contributed to the prevalence. Holstein cows are susceptible to specific genetic disorders. Jørgen reported that chondrodysplasia, complex vertebral malformation, syndrome of artheogyropsis and acroteriasis caused abortion and stillbirths while bovine progressive degeneration myeloencephlopathy, spinal muscular atrophy and osteognesis imperfeta resulted in calf mortality [5].

\section{Repeatability of threshold traits}

The estimate of abnormal birth rate was high, indicating that the variation in the trait could be to permanent environmental factors affecting the trait in Holstein Friesian cows and culling of cows based on this repeatability value may reduce the abnormal births in the 
herd. Further, this finding indicated that the type of calf (normal vs. abnormal) to be born in future gestation can be predicted based on type of calf born in the previous calving.

The repeatability of sex ratio was found to be very low $(0.038 \pm$ 0.0171 ) indicating that previous sex of the calf did not influence sex of subsequent pregnancy and the prediction of the sex of calf in subsequent calving was not possible based on the sex of calf in previous calving. Similar findings of very low repeatability have been also observed by Mukherjee et al. and Singh [12,20].

Mortality in female calves observed to be $0.060 \pm 0.028$. It indicated that frequency of mortality was $6.0 \%$ in second female calves of the cows whose first female progenies (calves) were died. This repeatability value was low that the death of previous calf had weak correlation to the survival of next calf. Therefore, this repeatability estimate cannot be considered sufficient to predict the mortality among female calves based on single observation.

The repeatability of replacement rate from total pregnancy showed strong correlation between successive records. However, the estimate for replacement rate based on female calves born from a cow was close to zero. The negative estimate was due to the variance analysis procedures of the model and in this case the degree of freedom error term was smaller than cow degree of freedom. This repeatability value was low and negative indicating a weak correlation between successive records of the cow on the trait. This repeatability value could not be used effectively to predict the replacement rate based on female calf born from a cow in subsequent calving.

\section{Conclusion}

The number of female calves reached to productive age is a function of birth types, sex ratio and calf mortality. There exists sufficient additive genetic variance affecting the type of birth, sex ratio, number of calves reaching to age at first calving. Therefore it is essential to genotype imported semen for any heritable disorders other than production traits only. This also demands the launching of efficient recording that will help identification such disorders. A good proportion of cows left the herd giving only one female calf or without replacement justifies the necessity of adequate reproduction management at all stages of pregnancy. Survivability of female calves can be improved through proper colostral and post colostral feeding of calves. Moreover, introducing sound herd health practices that boost calf hood survival and improves the number of female calves reaching to productive age.

\section{Acknowledgments}

The author would like to thank the Holeta Dam Station for allowing the data to be used in this study. I would like to thank Prof Singh for reviewing the manuscript.

\section{References}

1. Banik S, Naskar S (2006) Effect of non-genetic factors on replacement rate and its components in Sahiwal cattle. Indian J Anim Sci 76: 34-345.

2. Goshu G, Singh H (2013) Genetic and non-genetic parameters of replacement rate component traits in Holstein Friesian cattle. Springer Plus 2: 581.

3. HARC (Holeta Agricultural Research Center) (2008) Agro-metrological data report. Holeta, Ethiopia.

4. Tomar SS, Kumar A, Ajay K (1991) New approach for genetic analysis of proportion data without transformation. Asian J Dairy Res 10: 87-90.

5. Agerholm JS (2007) Inherited disorders in Danish cattle. APMIS Suppl 122: 1-76.

6. Donagh PB, Mairead LB, Margaret G, Simon JM (2011) Genetics of animal health and disease in cattle. Irish Vet J 64: 5.

7. Berry DB, Cromie AR (2006) Artificial insemination increases the probability of a male calf in dairy and beef cattle. Theriogenology $67: 346-352$.

8. Zobel R, Geres D, Pipal I, Buic V, Grane D, et al. (2011) Influence of semen deposition site on the claves sex ratio in Simmental dairy cattle. Reprod Domest Anim 46: 595-601.

9. Kumar A, Laviana GS, Tomar SS (1993) Genetic parameters of sex ratio in crossbred cattle. Indian J Dairy Sci 46: 41-42.

10. Atrey RK, Singh H, Sharma RK (2005) Factors affecting the productive herd life, longevity, and life time calf production traits in Frieswal cattle. Indian J Anim Sci 75: 1172-1175.

11. Fries F, Ruvinsky A (1999) The Genetics of Cattle. CABI Publishing, Biddles Ltd, UK.

12. Singh $L$ (2001) Genetics of replacement rate in Karan Fries cattle. $P h D$ Thesis, NDRI, Deemed University, Karnal, India.

13. Richard PJ, Row WS, Milo CW (1998) Effect of time of artificial insemination on pregnancy rates, calving rates, pregnancy loss, and gender ratio after synchronization of ovulation in lactating dairy cows. J Dairy Sci 8: 2139-2144.

14. Roche JR, Lee JM, Berry DP (2006) Pre-conception energy balance and secondary sex ratio-partial report for the Trivers-Willard hypothesis in dairy cows. J Dairy Sci 89: 2119-2125.

15. Delesa EK, Yohanne A, Alemayehu M, Samuel T, Yehualashet T (2014) Calve's sex ratio in naturally and artificially bred cattle in central Ethiopia. Theriogenology 82: 433-439.

16. Silva N, Stewrat S, Rapnicki P, Chang Y, Frick PM (2007) An observationa analysis of twin births, calf sex ratio and calf mortality in Holstein dairy calves. J Dairy Sci 90: 1255-1264.

17. Wudu T (2004) Calf morbidity and mortality in dairy farms in Debre Zeit and its environs, Ethiopia. MSc Thesis, Addis Ababa University, Faculty of Veterinary Medicine, Debre Zeit, Ethiopia.

18. Yalew B, Lobago F, Goshu G (2011) Calf survival and reproductive performance of Holstein-Friesian cows in central Ethiopia. Trop Anim Health Prod 43: 359-365.

19. Gebremedhin D (2008) Assessment of problems/constraints associated with artificial insemination service in Ethiopia. MSc Thesis, Addis Ababa University, Faculty of Veterinary Medicine, Debre Zeit, Ethiopia.

20. Mukherjee K, Tomar SS, Singh RB (2000) Variability in sex ratio. J Anim Res 34: $24-28$ 